\title{
In Memory of Nikolai Ivanovich Zelentsov (1941-2012)
}

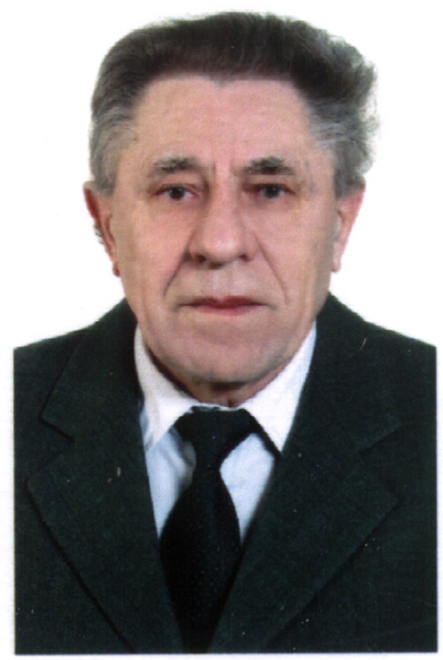

Nikolai Ivanovich Zelentsov.

Nikolai Ivanovich Zelentsov passed away suddenly on October 31, 2012 in the $72^{\text {nd }}$ year of his life. He was a wonderful person and an outstanding scientist.

For many years, since the 1980 s, we were friends with Nikolai Ivanovich. He never told us anything about his childhood, parents, or home life, always turning the corresponding questions into a joke. He was amazingly modest. His colleagues from the Institute of Biology of Inland Waters, Russian Academy of Sciences, helped us with the facts about Nikolai Ivanovich, allowing for more completely reconstructing his portrait.

N.I. Zelentsov was born on May 13, 1941 in the village of Spas (Danilovskoe raion, Yaroslavl oblast) to the family of a worker. His dad was killed in action in 1942. The hard life in a fatherless family during the postwar years left a mark on all further life of little Nikolai. From his childhood, he had to encounter the burden of long hours on the farm and bitter taste of fatherlessness. In 1948, Nikolai entered the Vakhtino secondary school, founded in Spas Village in 1918 and named after the Red Army.

The family had many children. Of all these children, Nikolai Zelentsov, who graduated in 1959, was the most diligent. Until the September of 1960, he worked on a collective farm as a machinery operator and then was in the Soviet Army to the August of 1963. Since his childhood, Nikolai
Ivanovich was fond of animals and entered the Leningrad Veterinary Institute as a full-time student in 1963 immediately after his military service. Nikolai Ivanovich for the first time got acquainted with the Institute of Biology of Inland Waters, USSR Academy of Sciences, when he was sent there for his pregraduate research training. During this training, he was involved in studies of the biology of fish gill parasites.

After graduating from the Veterinary Institute in 1968 , Nikolai Ivanovich was sent to work to Borok, where he came to know scientists working at the Institute of Biology of Inland Waters. Under the guidance of Alevtina Ivanovna Shilova, a candidate of biology at that time, a well-known expert in chironomids known in this country and abroad, Nikolai Ivanovich started his work as a senior laboratory assistant and then as a researcher with the Laboratory of Zoology, later renamed the Laboratory of Biology and Systematics of Aquatic Invertebrates.

From reminiscences of T.D. Zinchenko for this period of Zelentsov's life: "I met Nikolai Ivanovich in the house of Nina Yur'evna Sokolova (the scientific guide for my candidate of science dissertation and later, a reviewer for Zelentsov's dissertation). Later, being a postgraduate of Moscow State University, I had to leave Moscow for Borok during the Moscow Olympic Games. This coincided with the preparation of my candidate dissertation. At that particular time, bringing with me a big box of samples, books, and bibliographic cards and having arrived at the Institute of Biology of Inland Waters, I immediately found myself under the wing of Nikolai Ivanovich. He helped me with accommodation by giving me the keys for the apartment of a friend of his, who was away at that time, so that I would not spend my allowance on a hotel. A.I. Shilova gave her permission for Nikolai Ivanovich to work with the chironomids of the subfamily Orthocladiinae, which I sampled in the water pipeline weeds of the Uchinskii waterway. Over the whole month, we identified larvae, pupae, and imagoes and examined the perfect slides, made by Lyudmila Smirnova, a laboratory assistant to Shilova. We devotedly and enthusiastically studied the poorly identifiable species. Later, Nikolai Ivanovich confessed to me that it was the beginning of his creative life as well. Later we frequently met in Moscow at Sokolova's place; ever so often, after scientific talks and discussions of 


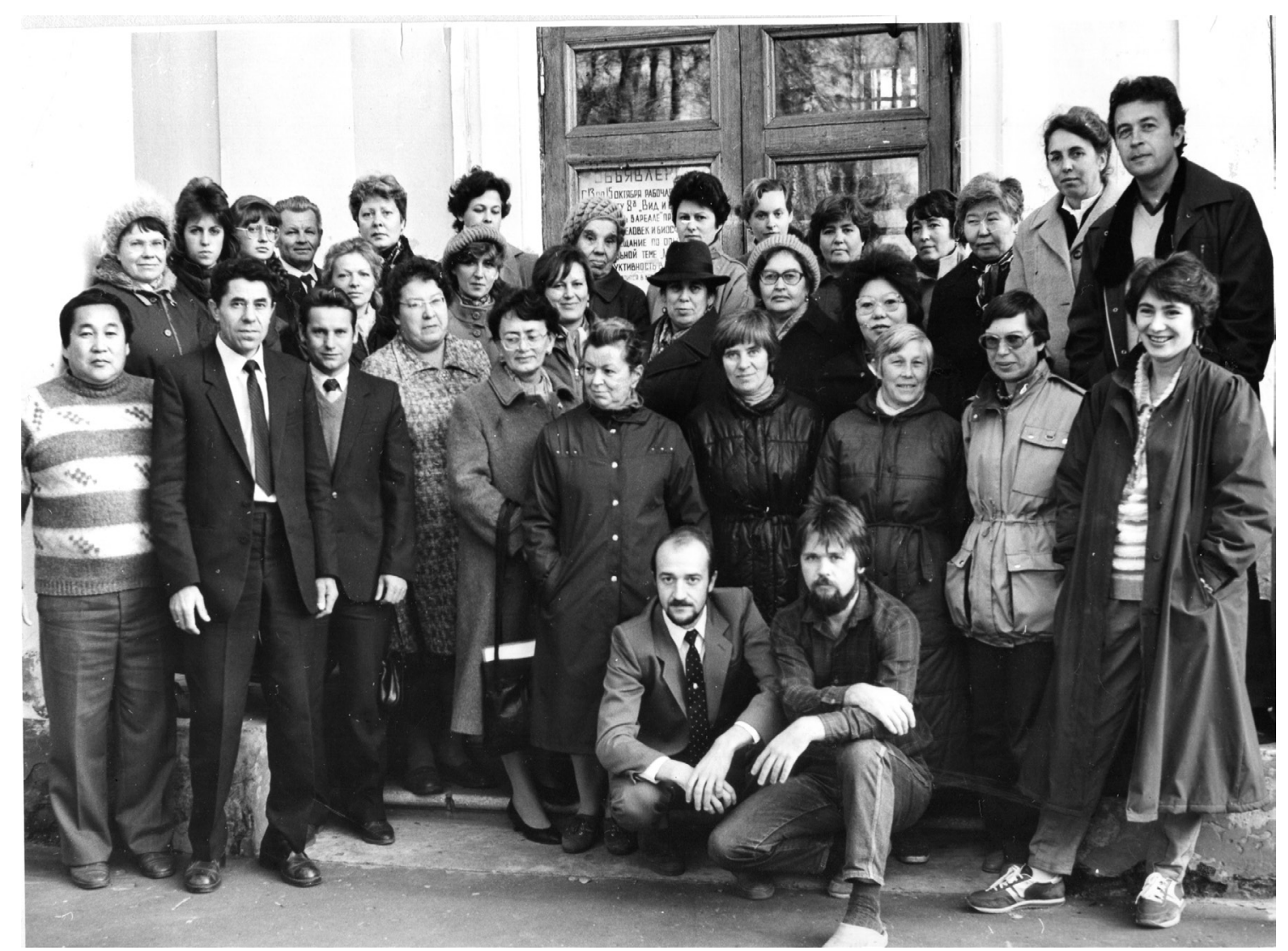

N.I. Zelentsov with colleagues on Conference of Russian chironomidologists (second from left side in first row). Borok, Yaroslavl Region, Institute of Biology of Inland Water, Academy of Sciences of the USSR. October 1983(?).

papers on chironomids, Nikolai Ivanovich fixed something in her apartment. He was a Jack-of-alltrades and an unattainable authority for me".

In 1985, Nikolai Ivanovich defended his candidate of science dissertation at the Chair of Invertebrate Zoology with Lomonosov Moscow State University titled Systematics and Biology of Orthocladiinae (Diptera): The Genera Psectrocladius Kieffer and Stackelbergina Shilova et Zelentzov. His dissertation involved systematics and biology of Orthocladiinae, a poorly studied chironomid subfamily, and for most species he examined not only imagoes, but also preimaginal stages.

Zelentsov studied the chironomid fauna in various regions of Russia and adjacent countries and was one of the leaders in the classical systematics of chironomids. Shilova and Zelentsov pioneered in making the annotated lists of chironomids for aquatic bodies of three regions, namely, subarctic part of the Krasnoyarsk krai (206 species), Severnaya Dvina River system (63 species), and Upper Volga River basin (259 species). In these regions, they discovered four previously unknown species as well as six genera and 69 species earlier not encountered in Russia.
Totally, Nikolai Ivanovich described two previously unknown genera and 13 species as well as revised many earlier described species and genera in the majority of cases providing comprehensive morphological descriptions for larvae and pupae too. All the corrections introduced by Zelentsov have been regarded as justified and added to the catalogs and keys to Holarctic and Palearctic chironomids.

Nikolai Ivanovich participated in the preparation of the Guidance Manual for Chironomid Study and is coauthor of two monographs, The Midge Chironomus plumosus L. (Diptera, Chironomidae) and The Atlas and Key to Karyotypes and Morphology of the Chironomiini Tribe Larvae.

Numerous specialists, postgraduate students, and applicants visited Nikolai Ivanovich to be consulted or trained in the issues associated with the Orthocladiinae biology and systematics, sampling technique, and cultivation, and he always shared his unique knowledge and rich experience. However, let's face it: not all of the persons who were consulted Nikolai Ivanovich acknowledged him in their papers. One cannot but listen to his advice. First and foremost, his colleagues recall a wonderful and cheerful personality, always friendly and 
delicate, who loved people and was true to his friends. Gentleness and eager assistance in any situation were his redeeming features. These features of his were most pronounced in field expeditions. During his trips to Astrakhan in 1982-1984, Nikolai Ivanovich collected chironomid imagoes in the Volga Experimental Fish-Breeding Plant in ponds, floodplain water bodies, and estuarial lakes. The staff eagerly became his devoted assistants, taking part in sampling and listening to his discourses on these insects. Nikolai Ivanovich tackled any heavy work, helped in "resolving" difficult situations, gave wise and good advice. The colleagues recollect that his open radiant smile extinguished any coming conflicts and revived spirits in most desperate situations. There was no person ill-disposed towards Nikolai Ivanovich. The colleagues in the lab trusted, respected, and adored Nikolai Ivanovich, regarded him as the fairest, most reliable, and generous person in the team. His diligence was amazing as well as the reliability and quality of his papers were admirable.

Zelentsov has stockpiled priceless material on several previously unstudied regions and succeeded in processing a considerable part of it. Unfortunately, eye problems interfered with the planned generalization of the overall data (many issues remained in draft sketches).

Nikolai Ivanovich deeply loved the wildlife of his native land, Yaroslavl area, was very fond of fishing, gathering mushrooms, and berries. The talks with him were always interesting and useful. Despite that deterioration of vision hindered examination of slides, Nikolai Ivanovich continued to participate in field work, the last of which took place on the Kama River. Whenever his colleagues called him, Nikolai Ivanovich said that he felt well and always wished them good health, saying "Be careful, Tatiana Dmitrievna, Evgenii Anatol'evich, or Margarita Mikhailovna (Aleksevnina), etc.", while they replied, "Take care of yourself, of your eyes, our beloved Nikolai Ivanovich, all of us need you so much!"

Nikolai Ivanovich was an attentive family man and loving husband, father, and grandfather. He devoted his inexhaustible supply of love, faithfulness, and industry to his family.

It is an infinite sorrow to recognize that Nikolai Ivanovich is not with us now, but we will retain the bright memories about this kind and good personality and an outstanding scientist.

May the memory of our friend, colleague, and great scientist - Nikolai Ivanovich Zelentsov - be imperishable.

\section{List of main publications by N.I. Zelentsov}

Poddubnaya, T.L, Mitropolsky, V.I., Shilova, A.I. and Zelentsov, N.I. 1971. Bottom fauna of the Rybinsk Reservoir by materials of 1968. Biology and physiology of freshwater organisms. Leningrad, Nauka: 42-55. (In Russian).

Shilova, A.I. and Zelentsov, N.I. 1972. Influence of photoperiodism on chironomid diapauses. Information bulletin of Institute of Biology Inner Water AN SSSR. N 13. Leningrad, Nauka: 37-42. (In Russian).

Zelentsov, N.I. 1974. Seasonal dynamics of quantity and biomass of chironomids from littoral of the Rybinsk Reservoir in 1970. Flora, fauna and microorganisms of the Volga River. Rybinsk, AN SSSR: 199-209. (In Russian).

Zelentsov, N.I. 1976. Metamorphosis and biology of Psectrocladius obvius (Walk.) and Ps. simulans (Joh.) (Diptera, Chironomidae). Biology and systematic of freshwater invertebrates. Yaroslavl: 103-128. (In Russian).

Zelentsov, N.I. 1978. Seasonal dynamic of chironomids in littoral zone of the Volzhsky Reach in the Rybinsk Reservoir in 1971-1972. Fauna of invertebrate and conditions for fish reproduction in littoral zone of the Verkhne-Volzhskih reservoirs. Rybinsk: 59-73. (In Russian).

Shilova, A.I. and Zelentsov, N.I. 1978. A new chironomid genus and species of Orthocladiinae subfamily (Diptera, Chironomidae). - Zoologicheskii zhurnal, 57 (10): 1584-1588. (In Russian).

Zelentsov, N.I. 1980. On systematics of Psectrocladius Kieff. Subgenus Psectrocladius s. str. Wülker (Diptera, Chironomidae). Biology, morphology and systematic of water invertebrates. Leningrad, Nauka: 192-231. (In Russian).

Zelentsov, N.I. 1980. Early stages of development and biology of Stackelergina praeclara Shilova et Zelentzov (Diptera, Chironomidae). Biology, morphology and systematics of freshwater invertebrates. Leningrad, Nauka: 232-238. (In Russian).

Zelentsov, N.I. 1980. Development of orthocladiinae Psectrocladius Kieff. (Diptera, Chironomidae) from Pamirs. Morphology and biology of freshwater invertebrates. Rybinsk: 110-135.

Zelentsov, N.I. and Akhrorov, F.A. 1981. Chironomids Psectrocladius Kieff. (Diptera, Chironomidae, Orthocladiinae) from Pamirs // Izvestia 
Akademii Nauk Tadzhikskoi SSR Dushanbe: «Donish», 3 (84): 71-74. (In Russian).

Shilova A.I., Pankratova V.Ya., Zelentsov N.I. 1982. Raising of chironomid preimafinal stages to adults. Workbook for chironomid study. Dushanbe. «Donish»: 23-29. (In Russian).

Zelentsov, N.I., Shilova, A.I. 1983. On chironomid fauna of the Astrakhan Region. Information bulletin of Institute of Biology Inner Water AN SSSR. Leningrad, 58: 27-31. (In Russian).

Shilova, A.I., Erbaeva, E.A., Linevich, A.A., Rodova, R.A., Zelentsov, N.I. et al. 1983. Systematics and morphology of Chironomus plumosus L. Chironomus plumosus L (Diptera, Chironomidae). Moscow, Nauka, 309p. (In Russian).

Zelentsov, N.I. 1985. Key on subgenera and species of Psectrocladius Kieff (Diptera, Chironomidae). Water communities and biology of hydrocoles. Leningrad, Nauka: 119-137. (In Russian).

Sherbina, G.K., Shilova, A.I. and Zelentsov, N.I. 1986. New and little-known chironomid species of the USSR fauna from Vishtynetsk Lake of Kaliningrad. Information bulletin of Institute of Biology Inner Water AN SSSR. Leningrad, Nauka, 65: 28-31. (In Russian).

Shilova, A.I. and Zelentsov, N.I. 1988. On chironomid fauna of the Caucasus (Diptera, Chironomidae). Information bulletin of Institute of Biology Inner Water AN SSSR. Leningrad, Nauka, 77: 35-36. (In Russian).

Shilova, A.I. and Zelentsov, N.I. 1988. On chironomid fauna of Sevan Lake (Diptera, Chironomidae). Information bulletin of Institute of Biology Inner Water AN SSSR. Leningrad, Nauka, 79: 48-51. (In Russian).

Makarchenko, E.A. and Zelentsov, N.I. 1988. Chironomids of the genus Psectrocladius Kieff. (Diptera, Chironomidae) from extreme North East of the USSR. Fauna, systematics and biology of freshwater invertebrates. Vladivostok: 40-51. (In Russian).

Zelentsov, N.I. 1989. New orthoclad species of Cricotopus van der Wulp and metamorphose of Acricotopus longipalpus Reiss (Diptera, Chironomidae) from Pamirs region. Biology, systematics and functional morphology of freshwater animals. Leningrad, Nauka, 56 (59): 215-249. (In Russian).

Kiknadze, I.I., Shilova, A.I., Kerkis, I.E., Shobanov, N.A. and Zelentsov, N.I. et al. 1991.
Karyotypes and morphology of Chironomini larvae. Atlas. Novosibirsk, Nauka: 1-115. (In Russian).

Zelentsov, N.I. 1991. A new species of Orthocladius van der Wulp (Diptera, Chironomidae) from Pamirs region. - Zoologicheskii zhurnal 70 (9): 95-103. (In Russian).

Shilova A.I. and Zelentsov, N.I. 1991. On systematics of the genus Einfeldia Kieffer, 1924 and Fleuria Kieffer, 1924. Information bulletin of Institute of Biology Inner Water AN SSSR. Leningrad, Nauka, 90: 46-49. (In Russian).

Zelentsov, N.I., Petrova, N.A. and Erbaeva E.A. 1992. Karyotype and morphology of Acricotopus lucidus from Mongolia. - Entomologicheskoe obozrenie 71(2): 295-301. (In Russian).

Zelentsov, N.I. 1993. A new orthoclad species of Acricotopus Kieff. (Diptera, Chironomidae) from region beyond the Arctic circle. - Freshwater invertebrates: biology, systematics, evolution. Proceedings of Institute of Biology of Inner Waters, 68(71): 113-146. (In Russian).

Zelentsov, N.I. and Shilova A.I. 1994. On chironomid fauna of Lithuania, Belarus, Ukraina and Moldova (Diptera, Chironomidae). Information bulletin of Institute of Biology Inner Water AN SSSR. Leningrad, Nauka, 97: 24-30. (In Russian).

Silina, A.E., Shilova, A.I. and Zelentsov, N.I. 1994. On study of chironomid fauna of small and middle rivers of small and medium-sized rivers of the central black earth region of Russia. - Condition and problems of Usmanskyi Bor ecosystems 4: 130-137. (In Russian).

Zelentsov, N.I. 1995. Metamorphoses of Vivacricotopus ablusus (Diptera, Chironomidae, Orthocladiinae) from region beyond the Arctic circle. - Zoologicheskii zhurnal 74(7): 58-64. (In Russian).

Zelentsov, N.I. and Shilova, A.I. 1996. Chironomid fauna (Diptera, Chironomidae) of Ust'Lenskyi Nature Reserve. - Biologiya Vnutrennikh Vod 1: 54-61. (In Russian).

Zelentsov, N.I. 1997. A new orthoclad species of Limnophyes Eaton from region beyond the Arctic circle (Note 1). - Zoologicheskii zhurnal 76(6): 712-717. (In Russian).

Zelentsov, N.I. 1997. A new orthoclad species of Cricotopus v.d. Wulp (Diptera, Chironomidae) from region beyond the Arctic circle (Note 2). - Zoologicheskii zhurnal 76(7): 810-822. (In Russian). 
Zelentsov, N.I. 2000. New orthoclad species of Propsilocerus (Diptera, Chironomidae) from Taimyr. - Zoologicheskii zhurnal 79(10): 1242-1246. (In Russian).

Shilova, A.I. and Zelentsov, N.I. 2000. Chironomid fauna (Diptera, Chironomidae) of region beyond the Arctic circle in Krasnoyarsk Territory. - Biologiya Vnutrennikh Vod 2: 49-57. (In Russian).

Zelentsov, N.I. 2001. A new orthoclad species of Cricotopus (Diptera, Chironomidae) region beyond the Arctic circle in Krasnoyarsk Territory. - Zoologicheskii zhurnal 80(9): 11461150. (In Russian).

Shilova, A.I. and Zelentsov, N.I. 2003. Chironomid fauna (Diptera, Chironomidae) of Upper Volga River basin. - Biologiya Vnutrennikh Vod 2: 27-34. (In Russian).

Petrova, N.A., Zelentsov, N.I., Klishko, O.K. and Chubareva L.A. 2003. First description of polytene chromosomes, larval morphology and biology of two species of Propsilocerus (Diptera, Chironomidae, Orthocladiinae). - Proceedings of Russian Entomological Society 74: 33-50. (In Russian).

Kuzmina, Ya.S., Shilova, A.I. and Zelentsov, N.I. 2003. Chironomid fauna (Diptera, Chironomidae) of Timan mountain ridge rivers. - Entomologicheskoe obozrenie 82(3): 590-597. (In Russian).

Petrova, N.A., Mikhailova, P.V., Chubareva, L.A., Shobanov, N.A. and Zelentsov, N.I. 2004. System of A.A. Chernovskyi (1949) as base for citotaxonomy of Chironomidae. - Euroasian Entomological Journal 3(4): 253-258. (In Russian).

Shilova, A.I. and Zelentsov, N.I. 2005. Revision of the genus Tribelos Townes (Diptera, Chironomidae). - Biologiya Vnutrennikh Vod 1: 32-37. (In Russian).

Zelentsov, N.I. 2006. A new orthoclad genus and species (Diptera, Chironomidae) from Novaya Zemlya Archipelago. - Zoologicheskii zhurnal 85(6): 775-779. (In Russian).

Zelentsov, N.I. 2007. A new chironomid species of Chaetocladius (Diptera, Chironomidae) from Novaya Zemlya Archipelago. - Zoologicheskii zhurnal 86(9): 1-5. (In Russian).

Zelentsov, N.I. 2007. Chironomid fauna of Novaya Zemlya and Severnaya Zemlya Archipelagoes (Diptera, Chironomidae). - Biologiya Vnutrennikh Vod 4: 15-19. (In Russian).
Kachvorian, E.A., Oganesian, V.S., Petrova, N.A. and Zelentsov, N.I. 2007. Species composition of chironomids and simuliids (Diptera, Chironomidae, Simulidae) of Razdan River in Armenia and hydrochemical features of river. - Entomologicheskoe obozrenie 86 (1): 73-82. (In Russian).

Sherbina, G.K. and Zelentsov, N.I. 2008. Chironomid fauna (Diptera, Chironomidae) of some reservoir and streams of Mongolia. - Biologiya Vnutrennikh Vod 1: 21-26. (In Russian).

Zelentsov, N.I. 2009. Chironomid fauna (Diptera, Chironomidae) of Khibin lakes of Kola Peninsula. - Eurasian Entomological Journal 8, suppl. 1: 89-92. (In Russian).

Loskutova, O.A., Zelentsov, N.I. and Sherbina, G.K. 2010. Amphibiotic insects of mountain lakes and streams of Ural. - Biologiya Vnutrennikh Vod 1: 13-22. (In Russian).

Sherbina, G.K. and Zelentsov, N.I. 2011. On chironomid fauna (Diptera, Chironomidae) of Sevan Lake. - Biologiya Vnutrennikh Vod 3: 11-14. (In Russian).

Petrova, N.A., Zhirov S.V., Zelentsov, N.I. and Kachvorian, E.A. 2011. On chironomid fauna (Diptera, Chironomidae) of Razdan River basin (Armenia). - Zoologicheskii zhurnal 90(4): 445-451. (In Russian).

Istomina, A.G., Zinchenko, T.D. and Zelentsov, N.I. 2012. Makarchenko Eugenyi Anatolievitsh (on his sixtieth birthday). - Samarskaia Luka: problems of regional and global ecology 21(4): 176-185. (In Russian).

Zelentsov, N.I., Baranov, V.A., Perkovsky, E.E. and Shobanov, N.A. 2012. First records on non-biting midges (Diptera: Chironomidae) from the Rovno amber. - Russian Entomological Journal 21(1): 79-87.

Zelentsov, N.I. 2013. On the chironomid fauna (Diptera, Chironomidae) of lakes of Karelia, Russia. - Eurasian Entomological Journal 12(1): 7-10. (In Russian). 


\section{Chironomid taxa described by N.I. Zelentsov}

Acricotopus maritimus Zelentzov, 1993

Arctosmittia Zelentzov, 2006

Arctosmittia biserovi Zelentzov, 2006

Chaetocladius makarchenkovi Zelentzov, 2007

Cricotopus breviantennatum Zelentzov, 2001

Cricotopus shilovae Zelentzov, 1989

Cricotopus trilobatus Zelentzov, 1997

Limnophyes sokolovae Zelentzov, 1997

Orthocladius (s. str.) multidentatus Zelentzov, 1991

Propsilocerus taimyrus Zelentzov, 2000

Psectrocladius (s. str.) delatoris Zelentzov, 1980

Psectrocladius (s. str.) fabricus Zelentzov, 1980

Psectrocladius (s. str.) sokolovae Zelentzov et Makarchenko, 1988

Stackelbergina Shilova et Zelentzov, 1978

Stackelbergina praeclara Shilova et Zelentzov, 1978

\section{Chironomid taxa named after N.I. Zelentsov}

Diamesa zelentzovi Makarchenko, 1989

Psectrocladius (s. str.) zelentzovi Makarchenko, 2003

Tatiana D. Zinchenko

Institute of Ecology of the Volga River basin of the Russian Academy of Sciences, Komzina Str., 10, Togliatti, 445003 Russia.

E-mail: tdz@mail333.com

Eugenyi A. Makarchenko

Institute of Biology and Soil Sciences, Russian Academy of Sciences, Far East Branch, 100 let Vladivostoku Avenue 159, Vladivostok 690022 Russia.

E-mail: makarchenko@biosoil.ru 